\title{
Generation, Composition and Management of Municipal Solid Waste at Rudraprayag, Garhwal Himalaya
}

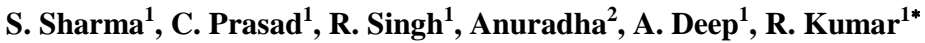 \\ ${ }^{1}$ Department of Environmental Sciences, H.N.B. Garhwal University (A Central University), \\ Srinagar Garhwal- 246174, Uttarakhand, India \\ ${ }^{2}$ Department of Environmental Sciences, Dr. Y. S. Parmar University of Horticulture and Forestry, \\ Solan (Nauni) - 173230, Himachal Pradesh, India
}

Received 26 April 2020, accepted in final revised form 3 August 2020

\begin{abstract}
The key objective of the current research effort was to investigate the generation and composition of the municipal solid waste and to assess the recent management practices for solid waste management. The study area was divided into nine wards and four zones on the basis of population size, their economic and living standards. The total solid waste generation during the study period was around 4-5 tonnes per day. The qualitative solid waste analysis of Rudraprayag reveals that it includes the biodegradable, non-biodegradable and inert waste. However, the quantitative solid waste analysis reveals that the highest generation of biodegradable waste was found in February (89.16 \%) and lowest in May $(79.06 \%)$. Non-biodegradable waste was recorded highest during March $(25.72 \%)$ and lowest during June $(7.73 \%)$. The percentage of inert waste was maximum during April $(2.87 \%)$ minimum during June $(0.037 \%)$. The total waste generation was found maximum during February which was $5883.983 \mathrm{~g}$. However, it was found minimum during May which was $2596.034 \mathrm{~g}$.
\end{abstract}

Keywords: Composition; India; Management; Rudraprayag; Uttarakhand.

(c) 2021 JSR Publications. ISSN: 2070-0237 (Print); 2070-0245 (Online). All rights reserved. doi: http://dx.doi.org/10.3329/jsr.v13i1.46853

J. Sci. Res. 13 (1), 165-182 (2021)

\section{Introduction}

Our planet "Earth" is the only known planet in the entire universe capable of supporting diverse life systems due to its unique atmosphere. The world saw a noticeable rise of consumers with the advent of industrialization and urbanization. Among various other things, the generation of solid waste is a uniformly increasing problem at the global, regional and local levels. This problem of an increasing rate of solid waste generation reaches critical magnitude in less developed countries rather than in highly developed countries due to unplanned urbanization and economic activities [1]. Increased urbanization and changing economic growth patterns are contributors of rising solid waste

\footnotetext{
${ }^{*}$ Corresponding author: rahul.khadwalia@gmail.com
} 
generation [2]. Advancement in living standards, technologies and rise in population, is leading towards high demand of energy and goods, which contributes in tremendous increase of solid waste generation rate [3]. The proper management, handling and removal of solid waste have become a serious concern for many less developed countries. Solid waste can be determined as the unwanted residue or leftover substance after any process or use generated from various sources including commercial, residential, industrial sector, etc. Solid waste can be a semi-solid, solid, non-liquid and non-gaseous product of anthropogenic activities, considered as being worthless and cannot be further utilized [4].

Production of a vast quantity of waste and its inappropriate dumping leads to aggregation of rubbish over the area. This not only destroys the landscape but also cause other impacts such as occupy and deteriorate large area of land, create a foul smell, unhygienic conditions, breeding of insects, rodents, pathogens which cause diseases like enteric fever, diarrhea, dysentery, malaria, infections and allergies, etc. The management of solid waste encompasses all such exercises that seek to reduce the health, environmental and aesthetic impacts of solid waste [5]. Management of solid waste aims to reduce or eliminate adverse impacts on the environment, on life forms, support economic development and improve the quality of living standards. A huge quantity of solid waste is generated daily and its proper and effective management is a challenging task. Solid waste is broadly categorized into household or municipal waste refers to solid waste from houses, streets and public centers, shops, offices, and hospitals. Management of municipal solid waste is most often the responsibility of municipal or other government authorities [6,7]. Industrial waste or hazardous waste has been generated from industries or related sectors in solid or semi-solid or non-liquid form. These kinds of waste are generally hazardous in nature due to their toxic effect. It may include chemicals, metals, paper, pesticides, plastics, rubber, glass, paints and associated wastes. Due to their corrosive, toxic or inflammable nature, these wastes are unsafe for the health of environment and other life forms [8]. However, biomedical waste contains infectious materials that may be solid or liquid.

Solid waste can also be classified on the basis of source of generation i.e., residential waste, agricultural waste, commercial waste, industrial waste, institutional waste and healthcare center waste (Table 1). On the basis of ecological content as biodegradable waste, non-biodegradable waste and inert waste. On the basis of physical characteristics as garbage generally includes kitchen waste and organic waste; rubbish consists of combustible and non-combustible waste excluding food waste like paper, wood, etc; trash may include waste which is dry and non-edible; ashes contains residue from the fire used for cooking or heating from on-site incineration; refuse consists all type of putrescible and non-putrescible waste except body waste and including litter waste, etc; dead bodiesanimals died naturally or accidentally remain leftover on roads or areas; and demolition and construction waste contains waste like broken concrete, roofing and sheathing scraps, rubble, plaster, pipes, etc. On the basis of hazard potential as hazardous waste, nonhazardous waste, combustible waste, non-combustible waste, radioactive waste, and infectious waste. Factors such as tourism, location, season, population, cultural activities, 
wastage, influences the amount of solid waste generated. Other than this, poor management, lack of techniques, unawareness as well as poor implementation part also contributes towards high waste generation.

Table 1. Different sources of solid waste and types of solid waste.

\begin{tabular}{lll}
\hline Source & \multicolumn{1}{c}{ Typical waste generation } & \multicolumn{1}{c}{ Type of solid waste } \\
Residential & $\begin{array}{l}\text { Waste generated from family or } \\
\text { houses }\end{array}$ & $\begin{array}{l}\text { Food waste, paper, vegetable and fruit waste, } \\
\text { plastic, polythene, metal, glass, ashes, garden } \\
\text { waste, dust, electronic waste, batteries, medicines } \\
\text { etc. }\end{array}$ \\
\hline Industrial & $\begin{array}{l}\text { Light and feavy } \\
\text { manufacturing, fabrication, } \\
\text { construction sites, power and } \\
\text { chemical plant, etc }\end{array}$ & $\begin{array}{l}\text { Housekeeping waste, packaging, food waste, } \\
\text { hazardous waste, ashes, special waste etc }\end{array}$ \\
\hline Commercial & $\begin{array}{l}\text { Stores, hotels, restaurants, } \\
\text { markets, office buildings, etc }\end{array}$ & $\begin{array}{l}\text { Paper, plastic, cardboard, plastic, wood, food waste, } \\
\text { glass, metal, special waste, hazardous waste etc }\end{array}$ \\
\hline Institutional & $\begin{array}{l}\text { Schools, hospitals, prisons, } \\
\text { government centers etc }\end{array}$ & $\begin{array}{l}\text { Paper, plastic, cardboard, plastic, wood, food waste, } \\
\text { glass, metal, special waste, hazardous waste etc }\end{array}$ \\
\hline $\begin{array}{l}\text { Construction } \\
\text { al and }\end{array}$ & $\begin{array}{l}\text { New construction sites, road } \\
\text { repairs, renovation sites, } \\
\text { Demolition }\end{array}$ & Wood, concrete, dust dirt, steel, etc \\
\hline Agricultural & $\begin{array}{l}\text { Crop, orchards, vineyard, } \\
\text { dairies, feedlots, farms etc }\end{array}$ & $\begin{array}{l}\text { Spoiled food waste, agricultural wastes, hazardous } \\
\text { wastes like pesticides etc. }\end{array}$ \\
\hline
\end{tabular}

Solid waste management and disposal is a distressing problem encountered by many of the urban and industrial areas in developing as well as developed economies. The problem has become one of the major urban environmental concerns. The alarming rise in concentration of solid waste at global scale, require implementation of efficient waste management procedures for sustainable environment. Tools such as life cycle assessment (LCA)can help evaluating the environmental performance of municipal solid waste management system that can provide support to decision-maker for developing efficient blueprints for waste management [9]. The degeneration time depends upon the existing type of waste or litter (Table 2). Waste generation profile varies from country to country, state to state and with season to season. High-income countries such as Australia, Japan, Hong Kong, China, Republic of Korea and Singapore produce 1.1-5 kg capita per day, low-income countries such as Bangladesh, India, Vietnam and Myanmar have a generation rate of $0.45-0.89 \mathrm{~kg}$ capita per day. In India, the total urban population of 240 million produces around 29 million tons of waste annually at an average rate of $0.33 \mathrm{~kg}$ per capita per day [10]. According to municipal council, the Uttarakhand state is generating approximately 3,000 metric tons of municipal solid waste every day of which only $40 \%$ is managed. The study aims to provide an extensive view regarding present state of solid waste in Rudraprayag city of Uttarakhand. It was initiated to gather information regarding the generation, composition and management of solid waste within municipal limits of Rudraprayag Municipal Corporation. The study also reveals the issues, concerns and practices related to solid waste management in the area. The study emphasis 
on assessing the possible environmental impacts related to improper management and suggesting some guidelines for proper, scientific and technical solid waste management to reduce implications related to improper solid waste management [11].

Table 2. Common type of litter generated and approximate time taken for its degeneration.

\begin{tabular}{ll}
\hline Type of litter & Approximate time taken for degeneration \\
\hline Organic waste (Food Waste, Fruit Peels etc) & $1-2$ weeks \\
Paper & $10-30$ days \\
Textile (Cotton cloth) & $2-5$ months \\
Wood & $10-15$ years \\
Woolen item & 1 year \\
Metal (Tin, Aluminum, Can etc) & $100-500$ years \\
Plastic & 1 million years \\
Glass & Not determined \\
\hline
\end{tabular}

Source: http://edugreen.teri.res.in

\section{Materials and Methods}

\subsection{The study area}

The Rudraprayag city lies at the confluence of Rivers Alaknanda and Mandakini (tributaries of Holy River Ganga). The District Rudraprayag covers an area of 1,984 square kilometers and lies at an altitude of 5,161 feet with the latitude of $30^{\circ} 17^{\prime} 04.61$ ' $\mathrm{N}$ and longitude of $78^{\circ} 58^{\prime} 56.26^{\prime \prime} \mathrm{E}$ (Fig. 1). As per the Indian Census, 2011 the district is having a total population of 2,42,285 individuals out of which 1,14,589 are males and the remaining $1,27,696$ are females with a population density of $122.12 / \mathrm{km}^{2}$. The district is having $81.30 \%$ literacy rate, which is $93.90 \%$ among the males and $70.35 \%$ among the females.

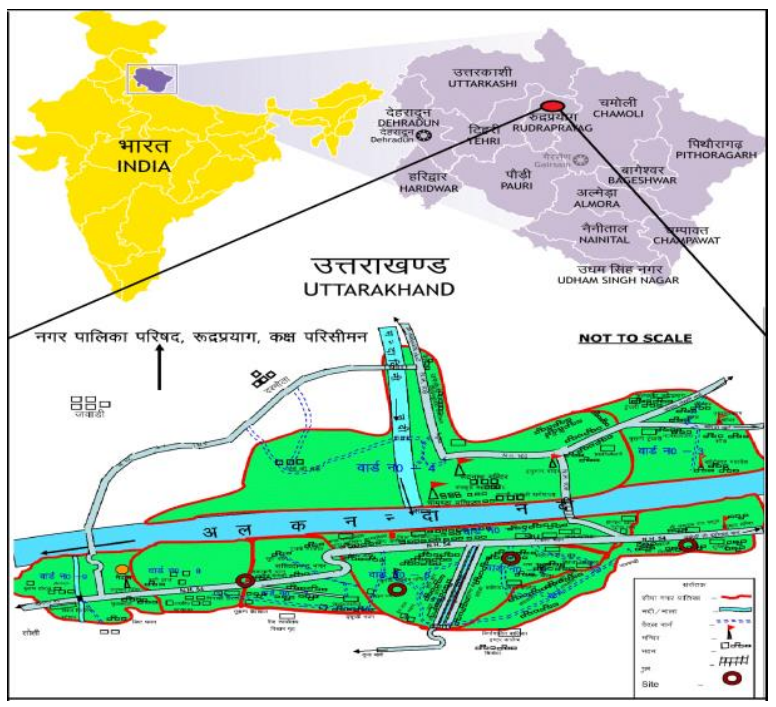

Fig. 1. Location map showing different wards and zones of the study area. 


\subsubsection{Solid waste management system}

The knowledge about the nature of wastes, its composition, physical and chemical characteristics and quantities are the primary steps for the planning of a solid waste management system. A preliminary survey of the different regions of the Rudraprayag city was done. The information related to waste generation and its management, municipality workers and their performance, etc, were collected from the municipal office of Rudraprayag. The area is divided into nine municipal wards. The total solid waste generation during the study period was around 4-5 tonnes per day (according to municipal officials). The management strategy and methods of the municipality were not appropriate at the time. But the performance of municipality from an outer aspect is quite convincing.

\subsubsection{Methodology used for the current study included the following}

i. The respondents were selected by using multistage stratified random sampling.

ii. Household waste collection as major source of information for the study.

iii. Collection of information from primary and secondary sources.

iv. Visit to the different locations of site where disposal of municipal solid waste took place.

v. Collection of information by means of interviews and questionnaires.

vi. Quantity determination of household generated wastes.

vii. Determination of moisture content of organic waste.

\subsubsection{Waste profile analysis}

i. Volume determination of distinct kinds of waste

ii. Extent of community understanding/awareness

iii. Performance of municipalities

iv. Associated environmental impacts

v. Health issues or other problems faced by residents (if any)

\subsubsection{Data will be obtained on the following basis}

\subsubsection{Primary data}

It included desk study by collecting information of the study area; a survey was done at the study area with the help of questionnaires to analyze the condition and public opinion, experiments in the laboratory were organized to assess the domestic waste, an evaluation was also done at the sampling sites, municipal officials and household residents were interacted through personal interviews to know the various aspects associated with the solid waste and in last direct investigations were also made to examine the condition of the study area. Multiple visits were made to different zones of the study area and the main dumping site for the disposal of solid waste. 


\subsubsection{Secondary data}

Information and data related to solid waste management of the study area was collected by interacting personally with the employees and other members of Municipal Corporation. The statistical data related to the study area was collected from the Statistical Department of Rudraprayag. Hospitals were also visited for the gathering of information related to the study area. Multiple visits were made to the municipality office and hospitals for an assemblage of information.

\subsubsection{Sampling sites}

The study was undertaken from January 2018 to June 2018 in which, four zones were selected on the basis of varying population and living standards. Ward no. 1 consisted of a highest population which is 1563 individuals and more likely to be the village area which was far from the main market (hence away from goods and services). Ward no. 7 consisted of a population of 1297 individuals and likely to be a village area that was nearby to the main market area (hence near to goods and services). Ward no. 6 comprised of a population of 1362 individuals and is a residential area with good family income. Ward no. 2 consisted population of 884 individuals and is a residential area with comparatively low incomes (Table 3). Three houses from each zone were randomly selected for sampling; hence a total of twelve houses were identified for sample collection. Sampling was done on a monthly basis for the estimation of solid waste generation in kilograms per capita per day.

Table 3. Details of different zones.

Source: Municipal council of Rudraprayag, 2011 census

ZONE I $\left(\mathrm{Z}_{1}\right)$ : Constituting ward no.1 which is generally a village area but their income status is comparatively high. The generated food waste is fed to their animals (cow, dog, etc). Solid waste is generally burned by them and other decomposable waste is buried or simply thrown over their fields. Hence, it can be assumed that their waste generation rate is low.

ZONE II $\left(\mathrm{Z}_{2}\right)$ : Constituting ward no. 2 which is comprised of residential and commercial area and their income status is less as compared to other wards of sampling. The generated food waste, solid waste and all types of other waste are disposed into the community bins. Hence, it can be assumed that their waste generation rate is high.

ZONE III $\left(\mathrm{Z}_{3}\right)$ : Constituting ward no. 6 which is comprised of residential and commercial area and their income status is more than that of ward no. 2. The generated food waste is given to the animals (cows, buffaloes, etc.) of nearby houses. Solid waste 
and all other types of waste are disposed off into the community bins. Hence, it can be assumed that their waste generation rate is moderate.

ZONE IV $\left(\mathrm{Z}_{4}\right)$ : Constituting ward no. 7 which is more likely a village area but is near to the main market and road and their income status is more than that of ward no.2 and 6 . The generated food waste is given to animals (cows, buffaloes, etc) in their houses. Solid waste is burned and all other types of waste are buried or dumped in their fields. Hence, it can be assumed that their waste generation rate is lower.

1) Evaluation of solid waste generated from households: Total waste generated for 24 $\mathrm{h}$ from each individual house was collected for sampling. Waste was weighted and segregated under the categories of biodegradable, non-biodegradable and inert waste. Further, the waste was segregated into sub-category viz: Biodegradable waste into food waste, paper waste or textile waste; non- biodegradable waste into plastic, polythene, glass, metal, medicine, etc. and for inert waste into hair waste and dust waste.The solid waste generation was calculated according to the formula:

Solid waste generation $(\mathrm{kg} / \mathrm{capita} /$ day $)=$

$$
\frac{\text { Solid waste generated/ day at a particular household }}{\text { Total number of residence of house hold during sampling }}
$$

2) Determination of moisture content: The components of organic waste were separated and weighed (this provides the initial weight of the sample) and placed in the oven at $105{ }^{\circ} \mathrm{C}$ for $1 \mathrm{~h}$. After this, the samples were cooled at desiccators and re-weighed (providing final weight). The percentage of moisture content was determined using the formula;

$$
\mathrm{M}=\frac{(\mathrm{W}-\mathrm{D}) \times 100}{\mathrm{~W}}
$$

Where, $\mathrm{M}=$ moisture content, $\%$

$\mathrm{W}=$ wet weight or initial weight of the sample, $\mathrm{kg}$

$\mathrm{D}=$ dry weight or final weight of the sample, $\mathrm{kg}$

3) Waste service index: The Rudraprayag municipality spent around INR 2,80,000 per month for the salaries of the workers and an additional cost of Rs.35,000 to 40,000 for fuel in the municipal vehicles. The municipality of Rudraprayag also invested an approximate amount of INR 7.0 lakhs per year on waste as miscellaneous charges (sources: municipality office).

4) Performance of municipality: The sweeper cleans the garbage twice a day and covers the entire municipal area. The vehicles make two trips in one shift; first shift from 6-10 am and second from 2-6 pm. Also there is door to door collection facility provided to the households. The municipality has not been providing any facility for on-site or off-site segregation of the waste. There is no area wise waste collection or differentiation in waste category. The waste is collected from the different sites and directly disposed off to the dumping site. No additional processing or any kind of treatment of waste is done so far. 
Hence, the collection, transportation and disposal of waste are a good fraction but the portion of segregation and treatment is meager.

5) Future strategy of municipality: The future strategy of the municipality of Rudraprayag has sorted out the waste into different categories and processing of segregated waste will be done at the dumping site. In order to reduce the amount of different waste such as metal, plastic, the municipality brought the compactor machine that can consolidate the solid waste of around six months into small packages which can be transported by a single truck hence minimizing the cost of transportation as well. Work for installation of the compactor machine has been started at the dumping site (Raitoli). Also, the future plan includes site development for land filling, pits with proper layering with Lucite for the decomposition of biodegradable waste.

6) Health status of municipal worker: There is no serious health hazard or disease caused to any worker of the municipality. Workers are provided with their uniforms, pair of gloves and masks. Their routine medical checkup is done from time to time. But the menace of monkeys is a cause of concern for workers.

7) Limitations to municipality: The area generates around 4-5 tonnes of solid waste per day which does not get segregated, and there is inadequate management of solid waste. There are several issue due to which municipality is lacking in their effectual performance. Some of them are:

i. Non availability of land area for processing the solid waste.

ii. Lack of funds and financial management plans.

iii. Municipality lacks in terms of man power, this is basically due to lack of funds, comparatively low salaries and poor economic support (according to municipal officials). Also there is an additional cost for diesel for garbage vans and trucks.

iv. Simian menace causes the trouble for sweeper and municipal workers. Monkeys create mess all over the roads and nearby places. Also there's always a threat of attack by them.

v. There is lacking monitoring system for prolific solid waste management.

vi. No responsibility is taken by administrative bodies for supporting municipality.

vii. The municipality urgently requires an authorized and appropriate dumping site.

viii. There is a need of a landfill site as well as some more vehicles and dumpers for the conservancy work.

ix. Lack of awareness among the general public worsen the conditions.

\section{Results and Discussion}

\subsection{Sampling of household waste}

The solid waste generated monthly was collected for a period of six months during January, 2018 to June, 2018 for 24 h from different houses of four selected zones. After its segregation into various categories, the moisture content of biodegradable waste was determined. The waste composition was estimated in percentage by comparing the data of six months obtained after sampling. The highest generation of biodegradable waste was 
found in the month of June $(92.23 \%)$ of total waste generated in that month whereas it was lowest in the month of April (72.38 \%) of total waste generated. Non-biodegradable waste was highest in the month of March (25.72\%) and lowest in the month of June (7.73 $\%)$. The percentage of Inert waste was highest in the month of April $(2.87 \%)$ of the total waste generated and lowest in June $(0.04 \%)$ of the total waste generated, as shown in Table 4. Waste generated from houses was calculated zone wise. The solid waste generated was calculated in $\mathrm{kg} /$ capita/day/house and also an average of solid waste generated in $\mathrm{kg} / \mathrm{month}$ in all sampling houses was calculated along with waste in $\mathrm{Kg} / \mathrm{six}$ month/house. The data obtained are presented in Table 5. The average solid waste generation (kg/capita/day/house) was found highest in Zone II and minimum in Zone I (Table 6). The total solid waste generation was found highest in Zone II (11345.418 g) and lowest in Zone I (2716.16 g) as mentioned in Table 6. Zone II is a commercial and residential area with low-income residences. The area lies nearby the main market hence there is the availability of sufficient goods and products. Data from the study area showed the trend of the highest waste generation of the low-income family. Similarly, Zone I is a village area but with good income families, and far from the market area showed the lowest solid waste generation of $2716.16 \mathrm{~g}$. As the place is a rural area, therefore, the waste was minimized by various methods like food waste was offered to their domestic animals, paper and related solid waste were set to fire in their fields and other solid waste was either dumped or buried in their fields.

Table 4. Monthly variations of different type of wastes $(\mathrm{g})$ in different households of different zones of Rudraprayag town during month January to June, 2018.

\begin{tabular}{|c|c|c|c|c|c|c|}
\hline 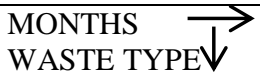 & $\begin{array}{l}\text { January } \\
(\mathrm{g})\end{array}$ & $\begin{array}{l}\text { February } \\
(\mathrm{g})\end{array}$ & $\begin{array}{l}\text { March } \\
(\mathrm{g})\end{array}$ & $\begin{array}{l}\text { April } \\
(\mathrm{g})\end{array}$ & $\begin{array}{l}\text { May } \\
(\mathrm{g})\end{array}$ & $\begin{array}{l}\text { June } \\
(\mathrm{g})\end{array}$ \\
\hline $\begin{array}{l}\text { Biodegradable } \\
\text { Waste }\end{array}$ & $\begin{array}{l}3046.768 \\
(77.43 \%)\end{array}$ & $\begin{array}{l}5246.265 \\
(89.16 \%)\end{array}$ & $\begin{array}{l}3681.32 \\
(73.94 \%)\end{array}$ & $\begin{array}{l}2596.604 \\
(72.38 \%)\end{array}$ & $\begin{array}{l}2052.445 \\
(79.06 \%)\end{array}$ & $\begin{array}{l}2593.201 \\
(92.23 \%)\end{array}$ \\
\hline $\begin{array}{l}\text { Non-Biodegradable } \\
\text { Waste }\end{array}$ & $\begin{array}{l}868.759 \\
(22.08 \%)\end{array}$ & $\begin{array}{l}604.97 \\
(10.28 \%)\end{array}$ & $\begin{array}{l}1280.357 \\
(25.72 \%)\end{array}$ & $\begin{array}{l}887.738 \\
(24.75 \%)\end{array}$ & $\begin{array}{l}533.216 \\
(20.54 \%)\end{array}$ & $\begin{array}{l}217.394 \\
(7.73 \%)\end{array}$ \\
\hline Inert Waste & $\begin{array}{l}18.869 \\
(0.48 \%)\end{array}$ & $\begin{array}{l}32.748 \\
(0.56 \%)\end{array}$ & $\begin{array}{l}17.088 \\
(0.34 \%)\end{array}$ & $\begin{array}{l}103.016 \\
(2.87 \%)\end{array}$ & $\begin{array}{l}10.373 \\
(0.40 \%)\end{array}$ & $\begin{array}{l}1.062 \\
(0.04 \%)\end{array}$ \\
\hline $\begin{array}{l}\text { Total waste } \\
\text { generation (gm) }\end{array}$ & $\begin{array}{l}3934.396 \\
(100 \%)\end{array}$ & $\begin{array}{l}5883.983 \\
(100 \%)\end{array}$ & $\begin{array}{l}4978.765 \\
(100 \%)\end{array}$ & $\begin{array}{l}3587.358 \\
(100 \%)\end{array}$ & $\begin{array}{l}2596.034 \\
(100 \%)\end{array}$ & $\begin{array}{l}2811.657 \\
(100 \%)\end{array}$ \\
\hline
\end{tabular}

The highest moisture content in percentage on an average was recorded in the month of February in Zone II while the lowest moisture content in percentage on an average was observed in the same month that is February in Zone I of the study area (Table 6). The possible explanation for highest moisture content as well as highest average solid waste generation found in Zone II of the study area can be the zone being a commercial as well as a residential area with families of low-income profile since there was no source of waste reduction by means of recycling and reuse. All the waste generated was dumped into community bins only. Hence, this can be a reason for the highest observed waste 


\section{Municipal Solid Waste}

generation. The highest waste generation was observed in the month of February (Table 5) and the possible observed reason for this was that in this period all works whether offices or schools are at peak intervals and into its functional state. Hence, the probability of solid waste generation got increased. Also in the month of June, most of the families traveled to other places (their hometown and relatives, etc.) due to the summer vacation of their children. Hence the rate of waste generation reduced in the area. The lowest moisture content, as well as a lowest average solid waste generation, was found in the Zone I of the study area and the possible explanation of this can be the zone being mostly a village area with families of the high-income profile, but far from the main market area. Therefore, it can be assumed that the availability of goods and different things was lesser.

Table 5. Monthly variations in quantitative generation of solid waste $(\mathrm{kg} / \mathrm{house} / \mathrm{month})$ in different households of different zones of Rudraprayag town during month January, 2018 to June, 2018.

\begin{tabular}{|c|c|c|c|c|c|c|c|c|c|c|c|c|}
\hline Zones & $\begin{array}{c}\text { House } \\
\text { No. }\end{array}$ & $\begin{array}{l}\text { Months } \\
\text { Family } \\
\text { Member }\end{array}$ & $\begin{array}{l}\text { January } \\
\text { (gm) }\end{array}$ & $\begin{array}{l}\text { February } \\
(\mathrm{gm})\end{array}$ & $\begin{array}{l}\text { March } \\
(\mathrm{gm})\end{array}$ & $\begin{array}{l}\text { April } \\
(\mathrm{gm})\end{array}$ & $\begin{array}{l}\text { May } \\
(\mathrm{gm})\end{array}$ & $\begin{array}{l}\text { June } \\
\text { (gm) }\end{array}$ & $\begin{array}{l}\text { Total } \\
\text { (gm) }\end{array}$ & $\begin{array}{l}\text { Zone wise } \\
\text { Total (gm) }\end{array}$ & $\begin{array}{l}\text { Avg. Solid } \\
\text { Waste Gen. } \\
\text { (Kg/capita/ } \\
\text { day/house) }\end{array}$ & $\begin{array}{l}\text { Average } \\
\text { (Kg/six } \\
\text { month/house) }\end{array}$ \\
\hline \multirow{3}{*}{ ZONE I } & H1 & 5 & 195.058 & 80.222 & 39.757 & 81.713 & 82.893 & 45.006 & 523.812 & \multirow{3}{*}{2716.16} & 0.007 & 0.087 \\
\hline & $\mathrm{H} 2$ & 5 & 199.432 & 207.467 & 323.491 & 474.76 & 146.257 & 247.583 & 1598.99 & & 0.022 & 0.266 \\
\hline & $\mathrm{H} 3$ & 6 & 52.595 & 63.625 & 201.196 & 128.396 & 103.189 & 44.357 & 593.358 & & 0.008 & 0.099 \\
\hline \multirow{3}{*}{ ZONE II } & $\mathrm{H} 4$ & 4 & 818.816 & 1058.1 & 207.532 & 332.021 & 220.489 & 427.838 & 3064.796 & & 0.057 & 0.511 \\
\hline & $\mathrm{H} 5$ & 5 & 665.616 & 718.705 & 687.137 & 985.496 & 465.039 & 625 & 4146.993 & \multirow{2}{*}{11345.418} & 0.057 & 0.691 \\
\hline & H6 & 4 & 483.593 & 1617.714 & 527.377 & 375.637 & 310.083 & 819.225 & 4133.629 & & 0.057 & 0.689 \\
\hline \multirow{3}{*}{$\begin{array}{l}\text { ZONE } \\
\text { III }\end{array}$} & $\mathrm{H} 7$ & 3 & 343.608 & 742.441 & 203.701 & 217.436 & 187.229 & 212.142 & 1906.557 & & 0.026 & 0.318 \\
\hline & $\mathrm{H} 8$ & 4 & 559.071 & 315.429 & 1595.711 & 383.641 & 389.433 & 134.319 & 3377.604 & \multirow{2}{*}{7162.393} & 0.047 & 0.563 \\
\hline & $\mathrm{H9}$ & 5 & 311.995 & 309.438 & 398.287 & 265.006 & 445.592 & 147.914 & 1878.232 & & 0.026 & 0.313 \\
\hline ZONE & $\mathrm{H} 10$ & 5 & 180.871 & 188.204 & 619.714 & 262.321 & 177.941 & 47.03 & 1476.081 & & 0.020 & 0.246 \\
\hline \multirow[t]{2}{*}{ IV } & H11 & 6 & 252.829 & 515.627 & 96.897 & 51.63 & 47.757 & 33.184 & 997.924 & \multirow{2}{*}{2762.443} & 0.014 & 0.166 \\
\hline & $\mathrm{H} 12$ & 5 & 65.97 & 67.011 & 77.965 & 29.301 & 20.132 & 28.059 & 288.438 & & 0.004 & 0.048 \\
\hline \multicolumn{2}{|c|}{ Total } & - & 3934.396 & 5883.983 & 4978.765 & 3587.358 & 2596.034 & 2811.657 & 23986.414 & & & \\
\hline \multicolumn{3}{|c|}{ Average ( $\mathrm{Kg} /$ month / house) } & 0.328 & 0.490 & 0.415 & 0.299 & 0.216 & 0.234 & & & & \\
\hline
\end{tabular}

Average $(\mathrm{Kg} /$ month / house $)=$ Total waste in all the household in a month/ total households $\mathrm{x} 1000$

Average $(\mathrm{Kg} / \mathrm{Six}$ month/ house $)=$ Sum of waste in a household in six months/ No. of months $\mathrm{x} 1000$

Table 6. Average moisture content (\%) in all the four zones during the month (January, 2018 to June, 2018).

\begin{tabular}{lllll}
\hline Months & Zone I $(\%)$ & Zone II $(\%)$ & Zone III $(\%)$ & Zone IV (\%) \\
\hline January & ND & 31.95 & 26.34 & ND \\
February & 7.19 & 81.34 & 31.03 & ND \\
March & 29.45 & 47.57 & 41.96 & 25.17 \\
April & ND & 39.17 & 43.13 & ND \\
May & 22.96 & 32.77 & 48.47 & ND \\
June & 18.63 & 50.89 & 43.51 & ND \\
\hline
\end{tabular}

The generated food waste was given to their animals (cow, dog, etc.). Solid waste was generally burned by the residents and other decomposable waste was buried or simply thrown over their fields. Hence, the assumed reason might be possible for the lowest waste generation. The research findings showed that there is the highest waste generation 
in low economic class families and lowest waste generation in high economic class families, which is similar in trend in Tamale and Kumasi of Ghana (South Africa) where the low-class areas generate more solid waste than the high-class region [12]. However, observation of Miezah et al. [12] in Ghana region showed that the areas located in high socioeconomic class generated the maximum amount of solid waste $(0.56 \mathrm{~kg} / \mathrm{person} /$ day $)$ and the areas located in low socioeconomic class generated minimum amount of waste $(0.47 \mathrm{~kg} / \mathrm{person} /$ day $)$. The waste generation amount depends upon factors such as demography and economic status as highlighted by Kathirvale et al. [13]. Similar observations were also reported by Asase [14] regarding waste generation differences among high socioeconomic areas $(0.63 \mathrm{~kg} /$ person/day) and low socioeconomic areas $(0.27$ $\mathrm{kg} / \mathrm{person} /$ day) of Kumasi metropolis (Ghana). Fobil et al. [15] and Owusu-Ansah [16] also reported similar data on generation rates among the different socioeconomic class areas in Accra (Ghana). In addition, the total average medicinal waste generated from houses was observed to be $19.193 \mathrm{~g}$ in the study area. The medicinal waste changes the chemical composition of solid waste, making waste hazardous in nature. This indicates the chances of hazardous impacts to the sweeper, municipal workers, straying animals (cows, donkeys and monkeys) and also to nearby residences.

\subsection{Hospital data}

Evaluation of hygienic and health status of the region and households were done. The study reveals that there were no severe cases recorded due to the inadequate management of solid waste. There were several recorded cases of different diseases (associated with solid waste) by the hospital officials. The data provided by the hospital authority is presented in table 7.

Table 7. Diseases and recorded cases in Rudraprayag District.

\begin{tabular}{lll}
\hline SL. No. & Diseases & Recorded cases \\
\hline 1. & Enteric fever & 329 \\
2. & Acute diarrheal disease & 488 \\
3. & Viral hepatitis and jaundice & 20 \\
4. & Acute respiratory infection & 1348 \\
5. & Bacillus dysentery & 28 \\
6. & Dysentery & 15 \\
7. & Malaria/Dengue & 0 \\
8. & Filariasis & 0 \\
& Total & 2228 \\
\hline
\end{tabular}

Sources: I.D.S.P unit of District Hospital of Rudraprayag

\subsection{Work done by municipal council}

There was inadequate waste management and poor maintenance of the solid waste management system. Also, there was inappropriate handling of waste by the municipality. The disposal system and treatment fraction were also inappropriate. Collected solid waste was disposed off on the roadside of the main dumping site in Raitoli. This created foul 
smell, destroys the landscape, aesthetic value of the area and can also deteriorate the nearby flowing Alaknanda River. Although, the waste management profile was not satisfactory the performance of the municipality and its workers was still appreciable, since the workers ensures the collection of solid waste at regular intervals and time. Municipality put numerous efforts to make the district clean.

Survey-based on questionnaires revealed that only $50 \%$ of people have knowledge about solid waste management. $50 \%$ of people were aware that kitchen waste can be recycled for other purposes and only $50 \%$ of the people segregated their solid waste in their houses. The remaining $50 \%$ didn't segregate their waste due to a lack of awareness and lack of time. $80 \%$ people were aware of the harmful impacts of dumping of solid waste inopen areas. $65 \%$ of people gave their waste to the municipality, $20 \%$ burned their waste and $15 \%$ gave their waste to animals. $30 \%$ of people generated paper waste, $25 \%$ of people generated organic (food) waste, $25 \%$ generated mixed waste (including paper, food, fruit, plastic, polythene, etc waste) and $20 \%$ generated plastic and polythene waste. $90 \%$ of people collected their waste daily; while $10 \%$ collected their waste once a week. $100 \%$ people were aware about the ban on polythene bags. Only $50 \%$ were aware of the harmful impacts of the use of polythene. $60 \%$ of people have stopped using polythene while $40 \%$ were still using polythene. Every day, $50 \%$ people of the total were using 1-2 polythene, $10 \%$ people were using 3-5 polythene, $10 \%$ were using more than 5 polythene bags and $30 \%$ were not using polythene at all. On asking $90 \%$ of people preferred to use jute bags while $10 \%$ preferred to use a polythene bag. $80 \%$ people were satisfied by the performance of municipal council while $20 \%$ were not and suggested more fidelity in the work of municipal council.

\section{Management of Municipal Solid Waste Generation}

\subsection{Integrated solid waste management (ISWM) system}

ISWM system refers to viable planning for all the functional elements which can be helpful in for an adequate waste management system. It consists of the collection and operation of relevant approaches, methodologies, machinery and management programs accomplished management of waste in sustainable manner [5].

\subsection{Components of solid waste management}

\subsubsection{Collection of solid waste}

i. Door to door collection- The door to door collection similar to block to block collection where the garbage collecting vehicle travels at regular route at prescribed intervals and stops at pre-determined point.

ii. Block collection- In this system, the garbage collection vehicle travels at regular route at prescribed intervals and stops at pre-determined points, where householders and street sweepers bring their garbage cans or buckets for emptying into the vehicle. It is also known as "Standing lorry system". 
iii. Curbside collection- In this system, garbage cans are left outside the premises of the road curb on the day the garbage van is to visit that area. This system can be successful only in developed areas, where is no danger of rag pickers and stray animals [17].

iv. Yard collection- Collection laborer enters property to remove waste.

\subsubsection{Segregation of solid waste}

Segregation of waste shall be promoted by recycling and reuse of separated material. Segregation of waste should be done at source itself or at the site of disposal. Community level segregation by means of community bins to separate different categories of waste.

\subsubsection{Storage of solid waste}

Solid waste storage at site is the first essential step of Solid Waste Management. The containers for an efficient waste collection system may fall under either of the following two categories: Stationary containers and hauled containers.

\subsubsection{Transport of solid waste (collection vehicles)}

The functional element of transfer and transport involves two steps: (i) The transfer of solid wastes from the vehicle having smaller capacity to the vehicle having larger capacity, and (ii) The subsequent transport of the wastes.

Other factors associated with transportation of solid waste include:

(i) Number of shifts and duration of the shifts per day.

(ii) Number of trips per shift; distance from transport the point of collection to the disposal.

(iii) Pay load per trip that can be collected that that carried in each trip

(iv) Methods of loading and un-loading.

(v) Regional transport authorities requirement and

(vi) Requirements from the point of view of hygienic and aesthetic demand of the citizens. Transportation equipment include hand cart, trolley, tractor, truck, tins, etc.

\subsubsection{Processing of solid waste}

Processing of solid waste can be done broadly in three kinds, these are:

\subsubsection{Machine based treatment}

Machine based processing plays an initial part in segregation, reduction and management of solid waste. The compactor machines are able to compact the waste like metal to its minimal size and huge quantity of waste can be loaded into a single truck for transport and further processing. 


\subsubsection{Thermal treatment}

This type of treatment involves heat treatment of solid waste to reduce composition of waste and obtain energy as byproduct. These are of following type;

(i) Incineration: In Incineration, combustible waste is burned at a very high temperature range $\left(900-1000{ }^{\circ} \mathrm{C}\right)$ in a closed chamber. While in preferable circumstances, it may decrease the waste quantity by $75 \%$ to $95 \%$ [18-20]. This method may cause air pollution and release toxic ash in the environment [21]. Nowadays, smokestacks are fitted with extraordinary accessories to trap these toxic air pollutants, but it is quite expensive [22].

(ii) Pyrolysis: Pyrolysis is the thermal decomposition of organic waste typically occurs under pressure and at temperatures above $430{ }^{\circ} \mathrm{C}$ in an inert atmosphere [8].

(iii) Open burning: Municipal waste is collected and directly burned in open area which causes smoke and other emissions to be released directly into the atmosphere to reduce the volume of waste. Open burning have many negative impacts on both human and environment.

\subsubsection{Biological treatment}

(i) Composting: It is a biological method of decomposition accomplished under the human regulated environments such as aeration, temperature, humidity, $\mathrm{pH}$ and sunlight. Here, microbes convert biodegradable organic waste into a humus-like substance called compost that can be used as fertilizer by the farmers in their agriculture fields. It is free from foul odor and harmful pathogens [23].

(ii) Vermicomposting: This process is very similar to composting but here earthworm species (Eiseniafetida, Red wiggler, European Night crawler and Octochaetonaserrata) have been used instead of microbes. This vermicompost is used by the farmers in their agriculture fields and households in their kitchen garden. It can make the soil fertile, act as a soil conditioner and responsible for soil aeration, etc. This material has been widely used by farmers across the country [24]. The vermicompost can provide a wide scope since it can eliminate surfactant from surface water hence balancing the nutrient content as well as maintain the $\mathrm{pH}[25]$.

\subsubsection{Disposal of solid waste}

(i) Open dumping: Solid waste collected from the different sources is simply dumped into one specific place where waste is accumulated. Solid waste collected from town more often deposited in low line areas especially in hills, usually in the outskirt of the towns in most of the underdevelopment and developing countries. Since open dumps are uncovered these attract flies, mosquitoes, insects and rodents, etc and provide a breeding ground for their multiplication. There is the severity of several health diseases and infections due to these pathogens. Open dumping leads to the foul smell and destroys the aesthetic beauty 
of the area. Although this method is unscientific and inappropriate, it is frequently practiced in different regions of India.

(ii) Land filling: In this approach, biodegradable organic waste is dumped into a natural or man-made pit which later covered with soil through machines [19,26]. Landfill sites can be useful in the following two ways: (i) as a source of biogas, and (ii) for reclamation of derelict sites to develop landscaped gardens, etc. Landfill sites generate considerable amounts of methane, which leaks from the soil cover. This presents a fire hazard and gives foul odor, but it can be collected and used as biogas. It also minimizes the amount of surface water entering into and gas escaping from the waste [27]. Landfill provides a successful pathway to practice waste management procedures when there is poor availability of infrastructure for recycling of waste [28].

\subsubsection{Use of ' $4 R$ ' policy}

i. Refuse: Refuse to buy new containers from the market and use the old containers that you already have with you.

ii. Reuse: Make use of things that are present in your waste. Like plastic bottles of cold drinks can be used again as water bottle. Instead of throwing away the soft drink cans or the bottles. They can be covered with homemade paper or paint on them and can be used as pencil stands or small vases.

iii. Recycle: Recyclable waste can be separated and send to recycling unit for further use. Use extra pieces of cloth to make shopping bags, pillow covers etc. which can be reused again and again. Recycling can proved to be a very good strategy for waste management alternatives [28].

iv. Reduce: Prefer to carry your own shopping bags that are made up of jute or cloth while going to market. Reduce the generation of unnecessary waste.

\section{Recommendations for the Proper Management of Solid Waste}

\subsection{At authority level}

i. Proper attention should be paid by the municipal committee for the effective management and disposal of the solid waste.

ii. The municipal solid waste of the area should be treated accurately by the application of specific techniques like land filling, composting, vermicomposting etc.

iii. Application of modern techniques by the municipal council for disposing biodegradable (composting, vermin-composting, energy recovery) and non-biodegradable (incineration, sanitary land filling) fraction of the solid waste of the area.

iv. The transportation vehicles should be covered to avoid foul odor and related health hazards.

v. Proper land away from any community area should be provided for solid waste dumping by the authority. 
vi. Bio processing of waste in order to obtain valuable resources such as energy that is ecofriendly in nature is one of the best alternatives for waste management [29].

vii. Strict implementation of rules made by Government on waste (Municipal Solid Waste (Management and Handling) Rules 2018, hazardous waste (Management and Handling rule 2018 etc.) should be ensured by the local authority.

viii. Use of polythene bags are banned in Uttarakhand hence the authority should ensure that there will be no use or transport of polythene bags and charges should be imposed on its use.

ix. Enforcement of laws and strict penalties should be imposed against those littering and polluting both land and river.

x. Use of some organic waste materials for further fruitful ways can provide an alternate option for waste utilization [30].

xi. Generation of awareness among local communities and people related to open dumping, open burning, and unsafe handling of solid waste will help to reduce the menace of unhealthy management of solid waste.

xii. The aim should be at zero waste management to go for long term sustainable solutions.

xiii. Appreciation, Rewards, credit should be provided to the individuals taking participation in municipal sanitation works.

\subsection{At community/public level}

i. Segregation of waste at initial level should be done by the people. The organic and non- organic waste should not be mixed at home.

ii. People should try to reduce, recycle and reuse the waste generated at their homes.

iii. People should not throw their waste in nearby places on in drains; instead the waste should be disposed in community bins.

iv. People should contribute in creating awareness related to solid waste management among others and should ensure that their locality remains clean.

v. Do not litter on roads and other public places.

vi. A good housekeeping can play an important role in reducing the problems arising out of improper and unmanaged solid waste to some extent.

vii. Give your efforts and contribution in making the city a waste free and clean place.

\section{Conclusion}

From the given study it has been concluded that it helps in determining several aspects related to solid waste management. The qualitative solid waste analysis of Rudraprayag reveals that the biodegradable waste includes food waste, paper waste, textile waste; the non-biodegradable waste includes plastic waste, polythene waste, glass waste, metal waste, medicinal waste and inert waste includes hair waste and dust waste. However, the quantitative solid waste analysis reveals that the maximum generation of biodegradable waste was found in the month of February $(89.16 \%)$ whereas it was minimum in the 
month of May (79.06 \%). Non-biodegradable waste was maximum in the month of March $(25.72 \%)$ and a minimum during the month of June $(7.73 \%)$. The percentage of Inert waste was maximum during April (2.87\%) minimum during June $(0.037 \%)$. The total solid waste generation was found maximum in Zone II with $11345.418 \mathrm{~g}$ whereas, it was found minimum in Zone I with $2716.16 \mathrm{~g}$. Converting waste into energy can not only provide a latest option of economy by energy derivation but also contributes in effective minimization of huge amount of waste.

\section{Acknowledgment}

The authors of this manuscript are thankfully acknowledging the entire working staff of Municipal Corporation of Rudraprayag (Uttarakhand) for their meaningful information, help and kind support throughout the period of study.

\section{References}

1. H. Kumar, Int. J. Manag. Social Sci. Res. (IJMSSR) 4, 1 (2015)

2. M. M. Mian, X. Zeng, A. A. N. B. Nasry, and S. M. Al-Hamadani, J. Mater. Cycles Waste Manag. 19, 1127 (2017). https://doi.org/10.1007/s10163-016-0509-9

3. J. Malinauskaite, H. Jouhara, D. Czajczyńska, P. Stanchev, E. Katsou, P. Rostkowski, and L. Anguilano, Energy 141, 2013 (2017). https://doi.org/10.1016/j.energy.2017.11.128

4. J. O. Babayemi and K. T. Dauda, J. Appl. Sci. Environ. Manage. 13, 83 (2009). https://doi.org/10.4314/jasem.v13i3.55370

5. C. Visvanathan, Solid Waste Management in Asian Perspectives Environmental Engineering and Management Program School of Environment (Resources and Development Asian Institute of Technology, 2006) pp. 1-15.

6. L. A. Guerrero, G. Maas, and W. Hogland, Waste Manag. 33, 220 (2013). https://doi.org/10.1016/j.wasman.2012.09.008

7. J. Bogner, IPCC (Intergovernmental Panel on Climate Change) Mitigation, Contribution of Working Group III to the Fourth Assessment Report of the Intergovernmental Panel on Climate Change, in Waste management, ed. B. Metz et al. (Cambridge University Press, 2007) Chapter 10 .

8. R. Rajput, G. Prasad, and A. K. Chopra, CJES 7, 50 (2009).

9. H. Khandelwal, H. Dhar, A. K. Thalla, and S. Kumar, J. Cleaner Product. 209, 630 (2019). https://doi.org/10.1016/j.jclepro.2018.10.233

10. R. K. Jeevan and M. V. Shantaram, Ind. J. Environ. Prot. 13, 721 (1993).

11. B. Gu, H. Wang, Z. Chen, S. Jiang, W. Zhu, M. Liu, Y. Chen, Y. Wu, S. He, R. Cheng, J. Yang, and J. Bi, Resour. Conservat. Recycl. 98, 67 (2015). https://doi.org/10.1016/j.resconrec.2015.03.001

12. K. Miezah, K. Obiri-Danso, Z. Kádár, B. Fei-Baffoe, and M. Y. Mensah, Waste Manag. 46, 15 (2015). https://doi.org/10.1016/j.wasman.2015.09.009

13. S. Kathirvale, M. N. M. Yunus, K. Sopian, and A. H. Samsuddin, Renew. Energy 29, 559 (2003). https://doi.org/10.1016/j.renene.2003.09.003

14. M. A. D. Asase, PhD thesis, Kwame Nkrumah University of Science and Technology, Kumasi (2011).

15. J. N. Fobil, D. Carboo, and N. A. Armah, Int. J. Environ. Technol. Manag. 5, 76 (2005). https://doi.org/10.1504/IJETM.2005.006508

16. K. Owusu-Ansah, M.Sc. Thesis, UNESCO-IHE Institute for Water Education, Delft, Netherlands (2008). 
17. M. S. A. Amin, M. M. Alam, and M. S. I. Mozumder, J. Sci. Res. 11, 133 (2019). https://doi.org/10.3329/jsr.v11i1.38457

18. M. Shafiq, S. Firdous, Q. Ifan, S. J. Khan, and A. Qadir, J. Sci. Res. 11, 365 (2019). https://doi.org/10.3329/jsr.v11i3.40493

19. N. Lakshminarasimaiah, PhD Thesis, Anna University, India (2014).

20. W. J. Schneider, U.S. Geological Survey (1970).

21. A. Kansal, Ind. J. Environ. Protect. 22, 444 (2002).

22. A. D. Bhide and A. B. Shekdar, International Solid Waste Association Times (ISWA) 1, 26 (1998).

23. V. M. Thomas and T. G. Spiro, Environ. Sci. Technol. 30, 82A (1996). https://doi.org/10.1021/es962098g

24. D. B. Botkin and E. A. Keller, Environmental Science-Earth as a Living Planet (John Wiley and Sons, New York, 2000) pp. 572-593. https://doi.org/10.1002/(SICI)1097-4660(199812)73:4<443::AID-JCTB967>3.0.CO;2-J

25. M. Islam, S. Sarker, M. Nasrin, M. Hoque, M. Islam, and M. Islam, J. Sci. Res. 12, 411 (2020). https://doi.org/10.3329/jsr.v12i3.45220

26. N. Ahsan, Ind. J. Environ. Protect. 19, 90 (1999).

27. M. Sharholy, K. Anmad, G. Mahmood, and R. C. Trivedi, Waste Manag. 28, 459 (2008). https://doi.org/10.1016/j.wasman.2007.02.008

28. A. Coban, I. F. Ertis, and N. A. Cavdaroglu, J. Cleaner Product. 180, 159 (2018). https://doi.org/10.1016/j.jclepro.2018.01.130

29. M. S. A. Amin, M. M. Alam, and M. S. I. Mozumder, J. Sci. Res. 11, 133 (2019). https://doi.org/10.3329/jsr.v11i1.38457

30. M. Shafiq, S. Firdous, Q. Ifan, S. J. Khan, and A. Qadir, J. Sci. Res. 11, 365 (2019). https://doi.org/10.3329/jsr.v11i3.40493 